\title{
SURGICAL MANAGEMENT OF DISTAL TIBIAL FRACTURES BY LOCKING PLATE/IMIL NAILING - A PROSPECTIVE STUDY OF RESULTS
}

\author{
Satya Kumar Koduru1, Aswanikanth T2 ${ }^{2}$, Prashanth Chalasani ${ }^{3}$, Srinivas Raghav T4, C. Hanumantha Rao ${ }^{5}$, Siddharth P6, \\ Venu Gopal Reddy P7, Venu Gopal T8
}

1 Professor, Department of Orthopaedics, NRI Academy of Sciences, Chinakakani, Andhra Pradesh. 2Junior Resident, Department of Orthopaedics, NRI Academy of Sciences, Chinakakani, Andhra Pradesh. ${ }_{3}^{3}$ Senior Resident, Department of Orthopaedics, NRI Academy of Sciences, Chinakakani, Andhra Pradesh. ${ }^{4}$ Senior Resident, Department of Orthopaedics, NRI Academy of Sciences, Chinakakani, Andhra Pradesh. 5 Professor and HOD, Department of Orthopaedics, NRI Academy of Sciences, Chinakakani, Andhra Pradesh. 6Junior Resident, Department of Orthopaedics, NRI Academy of Sciences, Chinakakani, Andhra Pradesh. ${ }^{7}$ Senior Resident, Department of Orthopaedics, NRI Academy of Sciences, Chinakakani, Andhra Pradesh. 8Junior Resident, Department of Orthopaedics, NRI Academy of Sciences, Chinakakani, Andhra Pradesh.

ABSTRACT
BACKGROUND
The aim of this study is to compare clinical and radiological outcomes of distal metaphyseal tibial fractures using locking compression
plates by open reduction technique or minimally invasive percutaneous plate osteosynthesis (MIPPO) technique or closed reduction
and IMIL nailing.
Settings and Design - This is a prospective study of 23 patients with distal tibial fractures who are presenting to our hospital from
July 2013 to September 2015, who are treated with ORIF with locking plate or IMIL.

\section{MATERIALS AND METHODS}

The study material includes data collection, clinical examination and investigations of 23 patients who underwent either ORIF/MIPPO with distal tibial LCP/IMIL for fractures of lower-third tibia admitted to NRI General Hospital, Chinakakani, attached to NRI Medical College, Chinakakani, had taken for this study after obtaining their informed, valid written consent. Of 23 patients, 14 patients underwent fixation with LCP both ORIF/MIPPO and 9 patients underwent fixation with IMIL. All surgeries done under Carm and followed regularly at 4 weeks, 8 weeks, 12 weeks, 6 months and annually thereafter. Clinical and functional results were assessed at followup.

\section{RESULTS}

Both these techniques provided adequate and comparable stability, fracture union and allowed early motion in distal tibial fractures. LCP is effective in extra-articular fractures occurring within $5 \mathrm{~cm}$ of joint where IMIL nails offend and do not provide adequate stability and where external fixators usually applied for primary stabilisation until soft tissue oedema get subsided, which delays the return to work with fixators. The intramedullary nailing is a safe, feasible and simple method of stabilisation of these fractures. This method is definitely a better alternative to external fixator and plating techniques in the management of open distal tibial fractures. Using fracture table to get satisfactory reduction, which can be maintained till completion of nailing and use of multiple distal locking screws in different plane to give stable fixation for early mobilisation and ambulation can minimise the complications. Impacting the unreamed nail till the subchondral bone of the distal tibia enhances the stabilisation.

\section{CONCLUSION}

These techniques had resulted in effective stabilisation of lower-third tibial fractures. Both techniques provided adequate and comparable stability, fracture union and allowed early motion; should be used according to clinical situation and surgeon's experience.

\section{KEYWORDS}

Distal Third Tibial Metaphysis, Locking Compression Plate, Minimally Invasive Percutaneous Plate Osteosynthesis (MIPPO), Intramedullary Interlocking Nailing (IMIL Nailing).

HOW TO CITE THIS ARTICLE: Koduru SK, Aswanikanth T, Chalasani P, et al. Surgical management of distal tibial fractures by locking plate/IMIL nailing - a prospective study of results. J. Evolution Med. Dent. Sci. 2016;5(97):7129-7133, DOI: $10.14260 /$ jemds/2016/1614

Financial or Other, Competing Interest: None.

Submission 06-01-2016, Peer Review 29-01-2016,

Acceptance 05-02-2016, Published 05-12-2016.

Corresponding Author:

Dr. Satya Kumar Koduru,

Flat 101, Kanchukota N. K. Habitate,

Gayatri Nagar,

Vijayawada-520008,

Andhra Pradesh.

E-mail: kodurusk@gmail.com

DOI: $10.14260 /$ jemds/2016/1614

\section{BACKGROUND}

Fractures of the distal third shaft and distal metaphysis of tibia are one of the difficult and challenging problems faced by orthopaedic surgeons. The problems associated with these fractures are due to the fact that distal third shaft and distal metaphysis of tibia are relatively less vascular. Since this area is having less soft coverage, even relatively low energy injuries can result in severe soft tissue damage and comminution of the fracture. These fractures are usually associated with fractures of the lower third of fibula, which need to be addressed separately to get well-aligned ankle mortise, unlike the 
proximal and mid-third shafts fractures of tibia, where fibular fractures need not always be treated separately. Nearby ankle joint (being a hinged type), poses unique problem. Any malunion disturbs the normal biomechanics of the ankle and foot, thereby leading to arthritis of the ankle and foot joints. The aim of the treatment of the distal tibial fractures is to achieve union of the fracture in normal alignment and regaining the stable, mobile and painless ankle joint while avoiding the infection and other complications.

These fractures can be treated with cast and braces in undisplaced, isolated injuries but the prolonged immobilisation, fracture displacement within the cast and ankle stiffness are the drawbacks. In the literature, there is no well-defined criterion about the best surgical method for these fractures. The fracture comminution, distance between the distal most fracture line to the ankle joint, soft tissue injury, associated fibular fracture, etc. influence the surgical method to be used in each patient.

Most of these fractures are managed with an operative intervention, such as closed reduction and Intramedullary Interlocking (IMIL) nailing or Open Reduction and Internal Fixation (ORIF) with plating or closed reduction and percutaneous plating or external fixators. Each of these techniques has their own merits and demerits. Recently, techniques of closed reduction and Minimally Invasive Plate Osteosynthesis (MIPO) with Locking Compression Plate (LCP) has emerged as an alternative treatment option for distal diametaphyseal tibia fracture. When applied subcutaneously LCP does not endanger periosteal blood supply, respect fracture haematoma and also provides biomechanically stable construct. 1,2

Compared with a conventional plate, a locking plate imparts a higher degree of stability and provides better protection against primary and secondary losses of reduction and minimisation of bone contact. Locking Plates (LPs) have the biomechanical properties of internal and external fixators with superior holding power, because of fixed angular stability through the head of locking screws, independent of friction fit. Traditional open reduction and internal fixation of such injuries results in extensive soft tissue dissection and periosteal injury and associated high rates of infection, delayed union and non-union. Similarly, external fixation of distal tibial fractures may also be associated with high incidence of complications with pin infection and loosening in over half of the cases and malunion rates of up to $45 \%$ are the drawbacks.

Minimally Invasive Plate Osteosynthesis (MIPO), already used with LC-DCPs has now become more popular with the development of the LCP. Through a small skin incision, the plate is tunnelled extraperiostally along the medial aspect of the tibia and fixed with head locking screws. MIPO offers many biological advantages including minimal soft tissue dissection with preservation of vascular integrity of the fracture as well as preserving osteogenic fracture haematoma. Experience of the application of these techniques to fractures of the distal tibia is less extensive and opinion regarding optimal technique varies.

Intramedullary Interlocking (IMIL) nailing of the diaphyseal fractures is a well-accepted method, but their role in the treatment of distal third shaft and metaphysis is controversial due to difficulties in fracture reduction, distal iatrogenic propagation of the fracture, hardware failure and inadequate distal fixation leading to malalignment. The distal widening of the medullary canal prevents the tight endosteal fit of the nail and compromises the reduction leading to rotational, translatory and angulatory deformity. The present study was conducted to evaluate the outcome of results of distal third tibial shaft fractures treated with IMIL nailing and locked plating in terms of fracture union rate, malunion, delayed union, nonunion and functional results like ankle and hind foot movements, gait, walking distance, etc. and methods to minimise the known complications.

\section{MATERIALS AND METHODS}

This is a prospective study from July 2013 to September 2015; 23 adult patients with fractures of lower third tibia admitted to NRI General Hospital, Chinakakani, attached to NRI Medical College, Chinakakani, will be taken for this study after obtaining their informed and valid written consent.

\section{Inclusion Criteria}

1. Adults (Aged more than 18 years) males and females.

2. Closed and open (Type I and Type II) Type A fractures of distal one-third of tibia.

\section{Exclusion Criteria}

1. Patients aged below 18 years.

2. Patients with articular involvement.

3. Patients not willing to undergo surgery.

4. Patients medically unfit for surgery.

On admission of the patient, a careful history was elicited from the patient and/or attenders to reveal the mechanism of injury and the severity of the trauma. The patients were then assessed clinically to evaluate their general condition and the local injury. General condition was assessed with the vital signs and systemic examination. Methodical examination was done to rule out fractures at other sites.

\section{RESULTS}

The age of the patients ranged from 23 - 62 years with the fracture being most common in the 4 th and 6 th decade and an average age of 42 years.

Out of 23 patients, $17(70 \%)$ patients were males and 6 (30\%) patients were females showing male preponderance because of traveling and working in fields and factories. There were $16(70 \%)$ patients with right distal tibia fractures, 7 (30\%) patients with left distal tibial fractures.

In our study, $16(70 \%)$ of patients sustained injury following road traffic accidents is 7 (30\%) patients sustained injury following fall.

Out of the 23 cases, $19(82 \%)$ cases were closed fractures and $4(18 \%)$ cases were open fractures.

Classification of the 4 cases of open fractures classified based on Gustillo Anderson classification of open fractures, 2 (50\%) was type I compound and $2(50 \%)$ were of type II compound.

The fracture pattern was classified based on Rudie and Allgower classification for fractures of distal tibia of the 23 cases studied, 5 (22\%) cases were A1, 8 (35\%) were A2, 10 (43\%) were A3.

10 of 23 cases studied had an associated fracture of the lower third of fibula. All the 23 cases were operated under lumbar sub-arachnoid block (spinal anaesthesia). All the cases 
studied underwent open reduction and internal fixation and closed reduction methods with MIPPO techniques with help of fluoroscopic control too and intramedullary interlocking nails. Followup ranged from 6 months to 12 months.

Of the 23 cases treated with locking compression plates and IMIL nailing 5 (22\%) cases took 31 - 40 minutes, 8 (35\%) took 41 - 50 minutes, $4(17 \%)$ took 51 - 60 minutes, 2 (9\%) took 61 - 70 minutes and $4(17 \%)$ took 71 - 80 minutes.

All the fractures united with an average of 16 weeks. There was 1 delayed union with 20 weeks' signs of radiological callus formation.

Fractures of $10(6 p+4 n)(43 \%)$ patients united in 14 weeks, $6(4 p+2 n)(26 \%)$ patients united in 16 weeks, $6(2 p+$ $3 n)(26 \%)$ fractures united in 18 weeks and in $1(1 n)(5 \%)$ patients the fractures united in 20 weeks.

Showing Objective Criteria

\begin{tabular}{|c|c|c|c|c|c|c|}
\hline 电 & 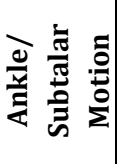 & 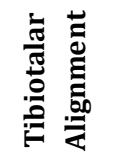 & 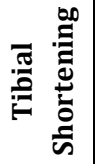 & 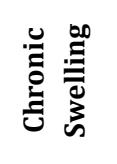 & 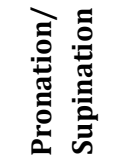 & 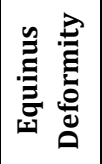 \\
\hline $\begin{array}{l}\text { Excel- } \\
\text { lent }\end{array}$ & $\begin{array}{c}>75 \% \\
\text { normal }\end{array}$ & Normal & None & None & Normal & None \\
\hline Good & $50-75 \%$ & Normal & None & Minimal & Normal & None \\
\hline Fair & $25-50 \%$ & $\begin{array}{c}<5 U \\
\text { Angula- } \\
\text { tion }\end{array}$ & $<1 \mathrm{~cm}$ & $\begin{array}{c}\text { Mode- } \\
\text { rate }\end{array}$ & $\begin{array}{c}\text { Moderate } \\
\text { decrease }\end{array}$ & None \\
\hline Poor & $<25 \%$ & $\begin{array}{c}>5 U \\
\text { Angula- } \\
\text { tion }\end{array}$ & $>1 \mathrm{~cm}$ & Severe & $\begin{array}{c}\text { Marked } \\
\text { decrease }\end{array}$ & Present \\
\hline
\end{tabular}

\section{Showing Subjective Criteria}

\begin{tabular}{|c|c|c|c|c|c|c|}
\hline 哭 & 톨 & 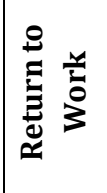 & 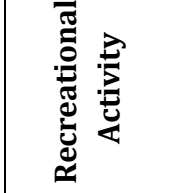 & 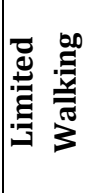 & : & $\stackrel{\varrho}{\Xi}$ \\
\hline 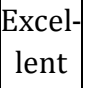 & None & $\begin{array}{l}\text { Same } \\
\text { work }\end{array}$ & Normal & No & None & None \\
\hline Good & Mild & $\begin{array}{l}\text { Same } \\
\text { work }\end{array}$ & $\begin{array}{c}\text { Mild } \\
\text { modification }\end{array}$ & No & None & None \\
\hline Fair & $\begin{array}{c}\text { Mode- } \\
\text { rate }\end{array}$ & $\begin{array}{l}\text { Modi- } \\
\text { fied }\end{array}$ & $\begin{array}{l}\text { Significant } \\
\text { modifica- }\end{array}$ & Yes & $\begin{array}{c}\text { Non- } \\
\text { Narcotic }\end{array}$ & Occasional \\
\hline Poor & Severe & Unable & None & Yes & Narcotic & Yes \\
\hline
\end{tabular}

At the end of 6 months of the 23 patients treated, $12(7 p$ $+5 n)(52 \%)$ patients had excellent outcome, $4(2 p+2 n)(17 \%)$ had good results, $4(3 p+1 n)(17 \%)$ had fair outcome and 3 $(1 p+2 n)(14 \%)$ patients had a poor result.

\section{Showing Objective Results}

\begin{tabular}{|c|c|c|}
\hline Results & No. of Cases & Percentage \\
\hline Excellent & 14 & 61 \\
\hline Good & 3 & 13 \\
\hline Fair & 2 & 9 \\
\hline Poor & 4 & 17 \\
\hline
\end{tabular}

Showing Subjective Results

\begin{tabular}{|c|c|c|}
\hline Results & No. of Cases & Percentage \\
\hline Excellent & 12 & 52 \\
\hline Good & 4 & 17 \\
\hline Fair & 4 & 17 \\
\hline Poor & 3 & 14 \\
\hline
\end{tabular}

\section{COMPLICATIONS}

\section{Intraoperative Complications}

There were no cases of intraoperative complications.

\section{Post-Operative Complications}

\section{Superficial Skin Infections}

Four of the patients developed superficial skin infections, which were treated with daily dressings and appropriate antibiotics after pus culture and sensitivity. All these infections subsided on the above said treatment.

\begin{tabular}{|c|c|c|}
\hline Complications & No. of Patients & Percentage \\
\hline Superficial skin infection & 4 & 20 \\
\hline Ankle movement restriction & & \\
$>75 \%$ & 0 & 0 \\
$50-75 \%$ & 1 & 0 \\
$25-50 \%$ & 1 & 4 \\
$<25 \%$ & 1 & 4 \\
\hline Anterior angulation $5^{\circ}$ & Table: Showing Complications \\
\hline \multicolumn{2}{|c|}{} \\
\hline
\end{tabular}

\section{Ankle Stiffness}

We had 2 patients with ankle stiffness. This was probably due to the incompliance of the patient to the advised physiotherapy regimen, as there was no means to monitor the physiotherapy of the ankle joint after discharge of the patient. Ankle stiffness ranged from restriction of ankle movement from $20 \%-40 \%$.

\section{Operative Photographs}

\section{Case No. 1}

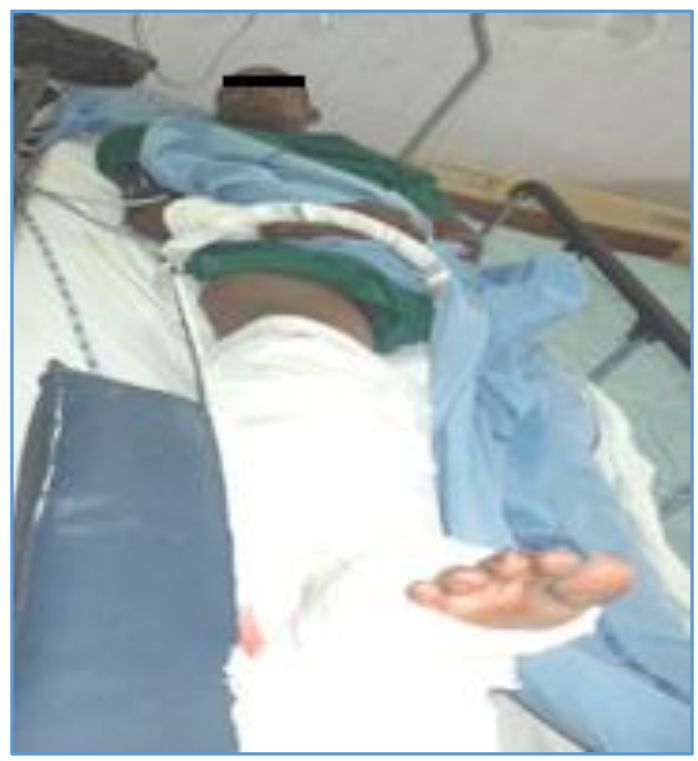



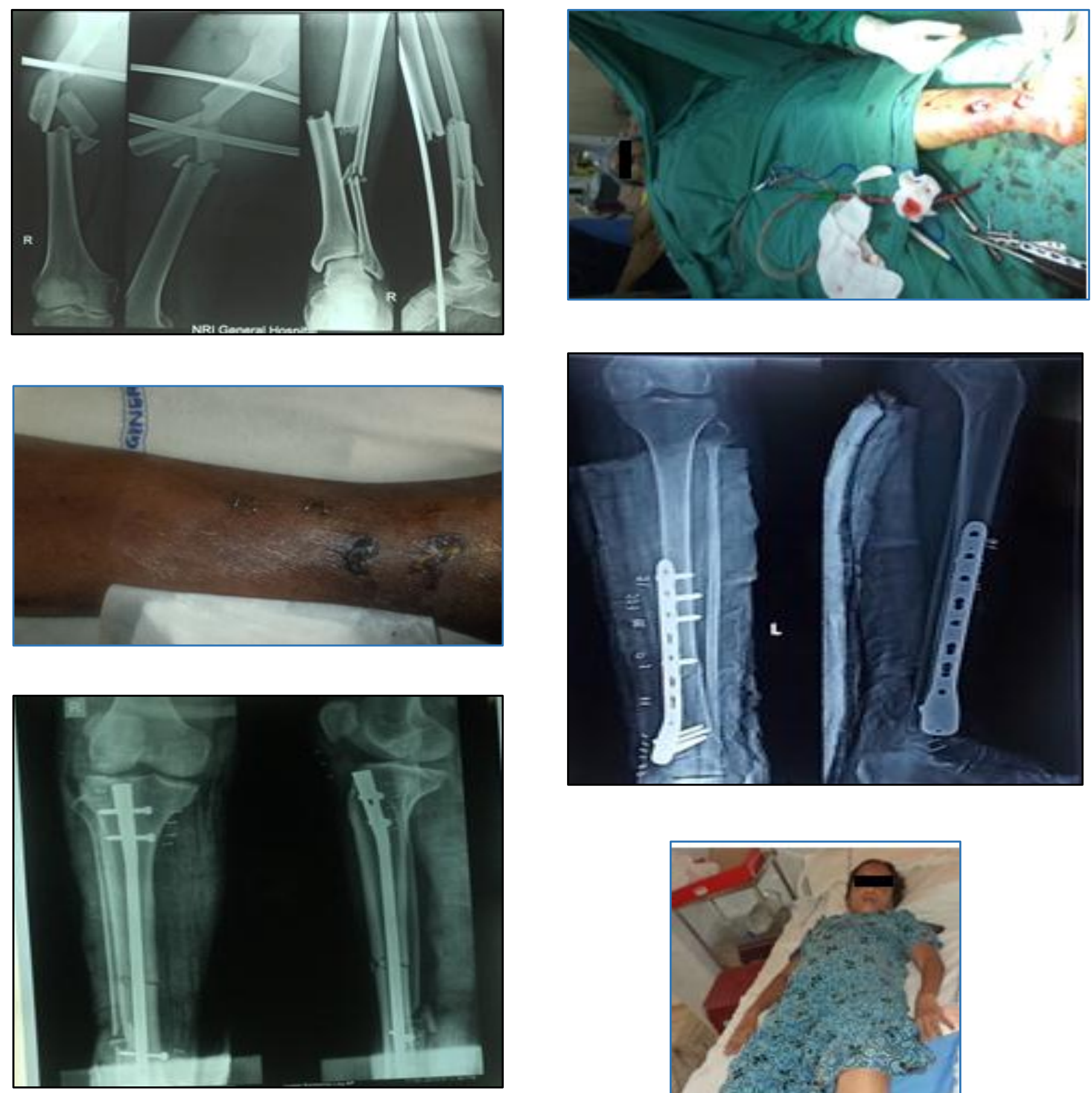

Case No. 2
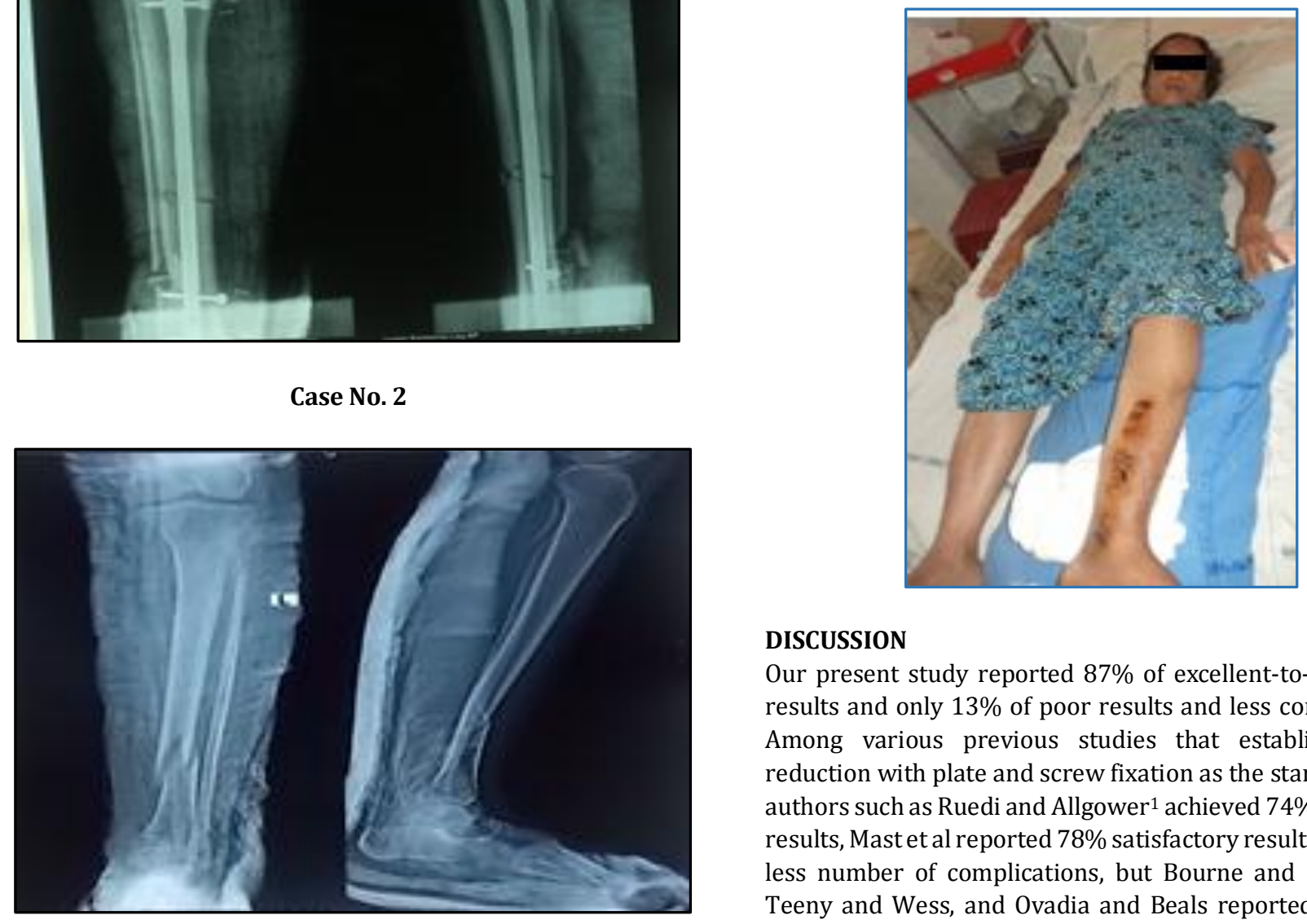

\section{DISCUSSION}

Our present study reported $87 \%$ of excellent-to-satisfactory results and only $13 \%$ of poor results and less complications. Among various previous studies that established open reduction with plate and screw fixation as the standard, some authors such as Ruedi and Allgower ${ }^{1}$ achieved 74\% acceptable results, Mast et al reported 78\% satisfactory results with much less number of complications, but Bourne and Colleagues, ${ }^{4}$ Teeny and Wess, and Ovadia and Beals reported only 44\%, $50 \%$ and $47 \%$ of excellent-to-satisfactory results respectively 
and also reported numerous complications like superficial infections, skin loss, osteomyelitis requiring either ankle arthrodesis or arthroplasty. These differences are probably due to differences in inclusion criteria, type of injury, type of fractures like more number of cases secondary to high-energy trauma and more number of Ruedi Type III fractures included and various patient factors and technical matters in later studies.

\begin{tabular}{|c|c|c|c|c|}
\hline Study & \multicolumn{2}{|l|}{ Methods } & Acceptable & $\begin{array}{c}\text { Not } \\
\text { A }\end{array}$ \\
\hline $\begin{array}{l}\text { Ruedi } \\
\text { and }\end{array}$ & \multirow{4}{*}{ ORIF-LCP } & 74 & 26 & \\
\hline Mast et al & & 78 & 22 & \\
\hline $\begin{array}{c}\text { Bourne et } \\
\text { al }\end{array}$ & & 44 & 56 & \\
\hline $\begin{array}{c}\text { Teeny } \\
\text { and Wiss }\end{array}$ & & 50 & 50 & \\
\hline $\begin{array}{c}\text { Im GI et } \\
\text { al }\end{array}$ & $\begin{array}{l}\text { ORIF-LCP/IMIL } \\
\text { Nailing }\end{array}$ & 88 & 12 & \\
\hline Gao et & \multirow{3}{*}{ MIPPO } & 87 & 13 & \\
\hline $\begin{array}{c}\text { Hazarika } \\
\text { et al }\end{array}$ & & 87 & 13 & \\
\hline $\begin{array}{c}\text { Ozkaya U. } \\
\text { et al }\end{array}$ & & 81 & 19 & \\
\hline $\begin{array}{l}\text { Present } \\
\text { study }\end{array}$ & $\begin{array}{c}\text { ORIF- } \\
\text { LC/MIPPO/IMIL }\end{array}$ & 87 & 13 & \\
\hline
\end{tabular}

NB: The excellent and good results have been tabulated as acceptable and the fair and poor results as not acceptable for easier comprehension.

Im GI et al, in a study of 30 patients using anatomic plates and screws, ORIF with LCP/IMIL nailing was done with $88.2 \%$ excellent-to-good results according to Oleurd and Mollander function ankle score and with a better alignment of fracture fragments. ${ }^{3}$

Hazarika et al, distal tibial fractures treated using locking compression plates through MIPPO technique, which aims to pressure bone biology and minimise surgical soft tissue trauma provided $87.5 \%$ of good-to-excellent results. ${ }^{4}$

Gao et al, studied patients with very short metaphyseal fragments in fractures of distal tibia treated with a polyaxial locking system. The polyaxial locking system showed excellent-to-good results in $87.3 \%$ cases. Thus, it may be a reasonable treatment option for distal tibia fracture with very short metaphyseal segments. ${ }^{5}$

Ozkaya $U$ et al, a retrospective review of 22 patients with distal third tibial fractures were treated with titanium locking compression plates by MIPPO technique offering good biological fixation of distal tibia, a total of $81 \%$ of good-toexcellent outcome was reported. 6

\section{CONCLUSION}

According to the study, 23 patients with fractures of the distal tibia had undergone locked compression plating by open reduction technique or MIPPO technique and closed reduction and IMIL nailing.
Both these techniques provided adequate and comparable stability, fracture union and allowed early motion in distal tibial fractures.

Locked plating not only helps in achieving reduction in difficult situation, but also in rapid union because it facilitates preservation of blood supply to the fragment, good anatomical reduction of fracture and fracture haematoma not being disturbed and is also effective in extra-articular fractures occurring within $5 \mathrm{~cm}$ of joint where IMIL nails offend and do not provide adequate stability and where external fixators usually applied for primary stabilisation until soft tissue oedema get subsided, which delays the return to work with fixators.

The intramedullary nailing is a safe, feasible and simple method of stabilisation of these fractures. Using fracture table to get satisfactory reduction, which can be maintained till completion of nailing and use of multiple distal locking screws in different plane to give stable fixation for early mobilisation and ambulation can minimise the complications. Impacting the unreamed nail till the subchondral bone of the distal tibia enhances the stabilisation and reduces the theoretical risk of damage to endosteal blood supply. This method is definitely a better alternative to external fixator and plating techniques in the management of open distal tibial fractures; $87.5 \%$ of goodto-excellent results. ${ }^{4}$

Gao et al, studied patients with very short metaphyseal fragments in fractures of distal tibia treated with a polyaxial locking system. The polyaxial locking system showed excellent-to-good results in $87.3 \%$ cases. Thus, it may be a reasonable treatment option for distal tibia fracture with very short metaphyseal segments. ${ }^{5}$

Ozkaya $U$ et al, a retrospective review of 22 patients with distal third tibial fractures were treated with titanium locking compression plates by MIPPO technique offering good biological fixation of distal tibia, a total of $81 \%$ of good-toexcellent outcome was reported. ${ }^{6}$

\section{REFERENCES}

1. Ruedi TP, Allgower M. The operative treatment of intra articular fractures of the lower end of tibia. Clin Orthop Relat Res 1979;138:105-10.

2. Kellam JF, Waddell JP. Fractures of the distal tibial metaphysic with intra-articular extension - the distal tibial explosion fracture. J Trauma 1979;19(8):593-601.

3. Im GI, Tae SK. Distal metaphyseal fractures of tibia: a prospective randomized trial of closed reduction and intramedullary nail versus open reduction and plate and screws fixation. J Trauma 2005;59(5):1219-23.

4. Hazarika S, Chakravarthy J, Cooper J. Minimally invasive locking plate osteosynthesis for fractures of the distal tibia - results in 20 patients. Injury 2006;37(9):877-87.

5. Gao H, Zhang CQ, Luo CF, et al. Fractures of the distal tibia treated with polyaxial locking plating. Clin Orthop Relat Res 2009;467(3):831-7.

6. Ozakaya U, Parmaksizoglu AS, Gul M, et al. Minimally invasive treatment of distal tibial fractures with locking and non-locking plates. Foot Ankle Int 2009;30(12):1161-7. 